\title{
Beyond participation! Social innovations facilitating movement from authoritative state to participatory forest governance in Ukraine
}

\author{
Simo Sarkki (iD · Taras Parpan • Mariana Melnykovych • Lyudmyla Zahvoyska • \\ Juriy Derbal $\cdot$ Nataliya Voloshyna $\cdot$ Maria Nijnik
}

Received: 24 February 2018/ Accepted: 18 February 2019/Published online: 7 March 2019

(C) The Author(s) 2019

\begin{abstract}
Tuning participatory processes is often insufficient to achieve transition from authoritative state to democratic and participatory forest governance due to institutional inertia and unwillingness to truly decentralize decision-making power. Social innovations as reconfigurations of relationships between state, market actors, civil society and science can help to meet concerns of local people about forest Ecosystem Services (ES). In Ukraine, the SwissUkrainian Forest Development (FORZA) pilot project
\end{abstract}

Electronic supplementary material The online version of this article (https://doi.org/10.1007/s10980-019-00787-x) contains supplementary material, which is available to authorized users.

S. Sarkki $(\bowtie)$

Department of Cultural Anthropology, University of Oulu, PO Box 1000, 90014 Oulu, Finland

e-mail:simo.sarkki@oulu.fi

T. Parpan

Ukrainian Research Institute of Mountain Forestry, Hrushevskoho Str. 31, Ivano-Frankivsk 76018, Ukraine e-mail: tarasparpan@gmail.com

M. Melnykovych · L. Zahvoyska

Institute of Ecological Economics and Management, Ukrainian National Forestry University, Generala

Chuprynky St. 103, Lviv 79057, Ukraine

e-mail: Mariana.Melnykovych@hutton.ac.uk

L. Zahvoyska

e-mail: lyudmyla.zahvoyska@nltu.edu.ua initiated a social innovation process complementing regional forest planning with local participatory community development plans in Transcarpathia. This paper examines what kind of changes need to accompany the succession of participatory practices in transition processes from authoritative state to democratic forest governance, and what are the lessons learned for social innovations based on the Ukrainian case study. This paper synthesizes knowledge on the FORZA case analyzed by inductive content analysis, and integrates these local level results with a national survey $(\mathrm{N}=244)$ on Ukrainian forest governance. Transition processes need to go "beyond participation" by (i) legal reforms to better acknowledge ES

M. Melnykovych · M. Nijnik

Social, Economic and Geographical Sciences Group, The James Hutton Institute, Craigiebuckler, Aberdeen, Scotland AB15 8QH, UK

e-mail: Maria.Nijnik@hutton.ac.uk

M. Melnykovych

European Forest Institute, St. Pau Art Nouveau Site - St. Leopold Pavilion, St. Antoni Maria Claret, 167, 08025 Barcelona, Spain

J. Derbal · N. Voloshyna

NGO FORZA, Agency for Sustainable Development of Carpathian Region, Mynayska 27/39, Uzhhorod 88000,

Ukraine

e-mail: Yuriy.derbal@forza.org.ua

N. Voloshyna

e-mail: Natalia.voloshyn@forza.org.ua 
important for local people, (ii) a change from an exclusive focus on timber to acknowledging multiple ES, (iii) changed spatial and temporal rationales of state-based governance, and (iv) recognition of local people as credible experts. Social innovations can detect key barriers to the transition during the policy experiments, and need to pay significant attention on how the novel practices can be sustained after the pilot, replicated elsewhere and up-scaled. Without such considerations, social innovation projects may only remain as a marginal curiosity.

Keywords Ecosystem services - Modes of participatory governance - Ladder of participation . Local people $\cdot$ Social innovations $\cdot$ Transition countries

\section{Introduction}

A common current mantra especially by environmental policy and governance scholars is that it is necessary to generate successive movement from authoritative, state-based, single resource governance to participatory and socially equitable governance empowering local communities (Arnstein 1969; Kooiman 2003; Folke et al. 2005; Wesselink et al. 2011; Paavola and Hubacek 2013; Cent et al. 2014). Also policy makers are starting to notice this (e.g. UN Sustainable Development Goals, at https:// sustainabledevelopment.un.org/?menu=1300; Sotirov et al. 2016). Participation by local communities in governance decisions can yield important benefits for resilience, environmental and social sustainability, and adaptive governance that can help to cope with ongoing social-ecological changes (Folke et al. 2007; Berkes 2009).

Despite the high expectations associated with stakeholder participation, participatory governance still often fails to meet its goals, especially as regards environmental performance (Newig et al. 2017). In addition, even in decentralized participatory processes the state is still likely to dominate the environmental decision-making (Dryzek et al. 2003: 196). For example, democratic forest governance processes implemented by the state may still include participatory deficiencies (Raitio 2012; Sarkki and Karjalainen 2015). Therefore, it seems that approaches calling simply for more participation are largely failing because they are not accompanied by other changes needed in the successive movement from authoritative state towards participatory and democratic governance. These changes concern, for example, the concrete distribution of Ecosystem Services (ES) between various stakeholders, and the position of local decision forums within a multi-level governance context (MA 2005; Pascual et al. 2014; Primmer et al. 2015; Verburg et al. 2016).

Leading from above, the key assumption underpinning the present paper is that in order to move from authoritative to participatory governance there is a need to go "beyond participation", understood as fine tuning of participatory processes, to initiate lasting changes. This is because state-based changes in participatory practices often fail to create successive change due to institutional inertia or just unwillingness to share power (Beunen and Patterson 2016). Therefore, there is a need to look for additional innovative ways that can introduce and reveal changes that are needed to accompany participation for genuine movement from authoritative to participatory governance.

Social innovation initiatives are an alternative to state-based governance and provide examples that can integrate local participation into a larger existing governance framework (see EC 2014; Baker and Mehmood 2015; Dennis et al. 2016; Avelino et al. 2017; GRAID 2017). Social innovations in forest governance are defined in the present paper as "reconfigurations of relationships between state, market actors, civil society and science that facilitate a movement from authoritative state to participatory forest governance to better meet the concerns of local people on the use of ecosystem services". The present paper examines such social innovations initiated by a pilot research project addressing Ukrainian forest governance.

The Ukrainian case is interesting because there stakeholders expect a shift away from the current authoritative, sector-based forestry governance to more participatory practices in order to correct the bias favoring timber production over other forest ES. The transition from command and control style forest governance towards participatory governance processes in Ukraine is particularly interesting as path dependency in the post-Soviet context hinders gradual changes from authoritative state to well-functioning democracy (c.f. Nijnik and Oskam 2004; Nijnik and 
van Kooten 2006; Bizikova et al. 2012; Melnykovych and Soloviy 2014; Zahvoyska et al. 2015; Soloviy et al. 2017; Melnykovych et al. 2018a, b; Nijnik et al. 2018). To gain insights on social innovations that aim to introduce more effective participation, we examine the Swiss-Ukrainian Forest Development Project in Transcarpathia (the FORZA project). We synthesize results from minutes of the participatory meetings that took place during the FORZA project, and complement these with insights from publications, scientific papers and reports. In the Ukrainian context, an innovative aspect of the FORZA project was that, in collaboration with all relevant authorities, it combined extensive local community development planning with existing subnational regional forestry planning. We also connect the findings from the pilot FORZA project to current national-level Ukrainian forest governance by using insights from the forest law enforcement and governance survey $(\mathrm{N}=244)$ conducted in 2014 and 2016.

The objective of the present paper is to examine how social innovations can initiate movement from authoritative state to participatory forest governance for multiple ES. We operationalize this objective via three interrelated research questions:

- What are the modes along the continuum from authoritative state to participatory forest governance, and what kind of complexities arose regarding the identified modes in the case of the FORZA project?

- What kind of changes need to accompany the introduced participatory practices to make an impact on the existing use and governance of ES in an authoritative governance context?

- What are the lessons learned for social innovations drawn from the FORZA case?

The paper begins by introducing four modes on the way from authoritative state to participatory forest governance for multiple ES. After providing background on the FORZA project and the materials and methods, we analyze the complexities associated with the four modes in the FORZA case connected to national-level survey results. The discussion section identifies and explores the other changes that need to accompany novel participatory practices and the lessons learned for social innovations in forest governance. We end with brief conclusions, and highlight that while a definitive conclusion about the lasting impacts of the pilot project is difficult, the pilot introduced innovative governance practices that may serve as examples for wider-scale changes.

The present paper provides valuable evidence to the existing knowledge gap on how to move from authoritative state to participatory forest governance in Ukraine, synthesizing scattered knowledge on the FORZA case into a coherent and novel analysis by employing the results of the national survey on forest governance. This paper also adds knowledge and contributes to a key theme tackled by this special issue: to identify barriers that hinder the integration of practitioners' and scientists' knowledge and concerns into participatory ES governance, especially in countries under transition towards well-functioning democracy.

\section{Conceptualizing forest governance}

Environmental governance can be defined as decisionmaking involving interplay within a triangle consisting of state-based actors, market actors and civil society including local communities, NGOs and citizens (Lemos and Agrawal 2006). Scientists can be included as a fourth type of societal group, important for governance (see Pohl 2008; Primmer et al. 2015; Sarkki 2017). For example, participatory scientific approaches can facilitate community engagement in previously state-based decision-making (Stokols 2006; Sarkki et al. 2013) and function as initiators of social innovations enhancing democracy in forest governance.

To conceptualize the movement from authoritative state to participatory forest governance, we apply the basic idea of a ladder of participation in which quality of participation can take many forms (Arnstein 1969; Cent et al. 2014). Figure 1 proposes a ladder of participatory governance distinguishing between hierarchical, participatory and self-governance (see Kooiman 2003).

Hierarchical governance is most commonly associated with an authoritative state, in which a single authority makes decisions without opportunities for participation by civil society actors and local communities. Hierarchical governance can also relate to power of experts, who dominate the environmental decision-making. Whereas the former Soviet Union provides a typical example of an authoritative state, 


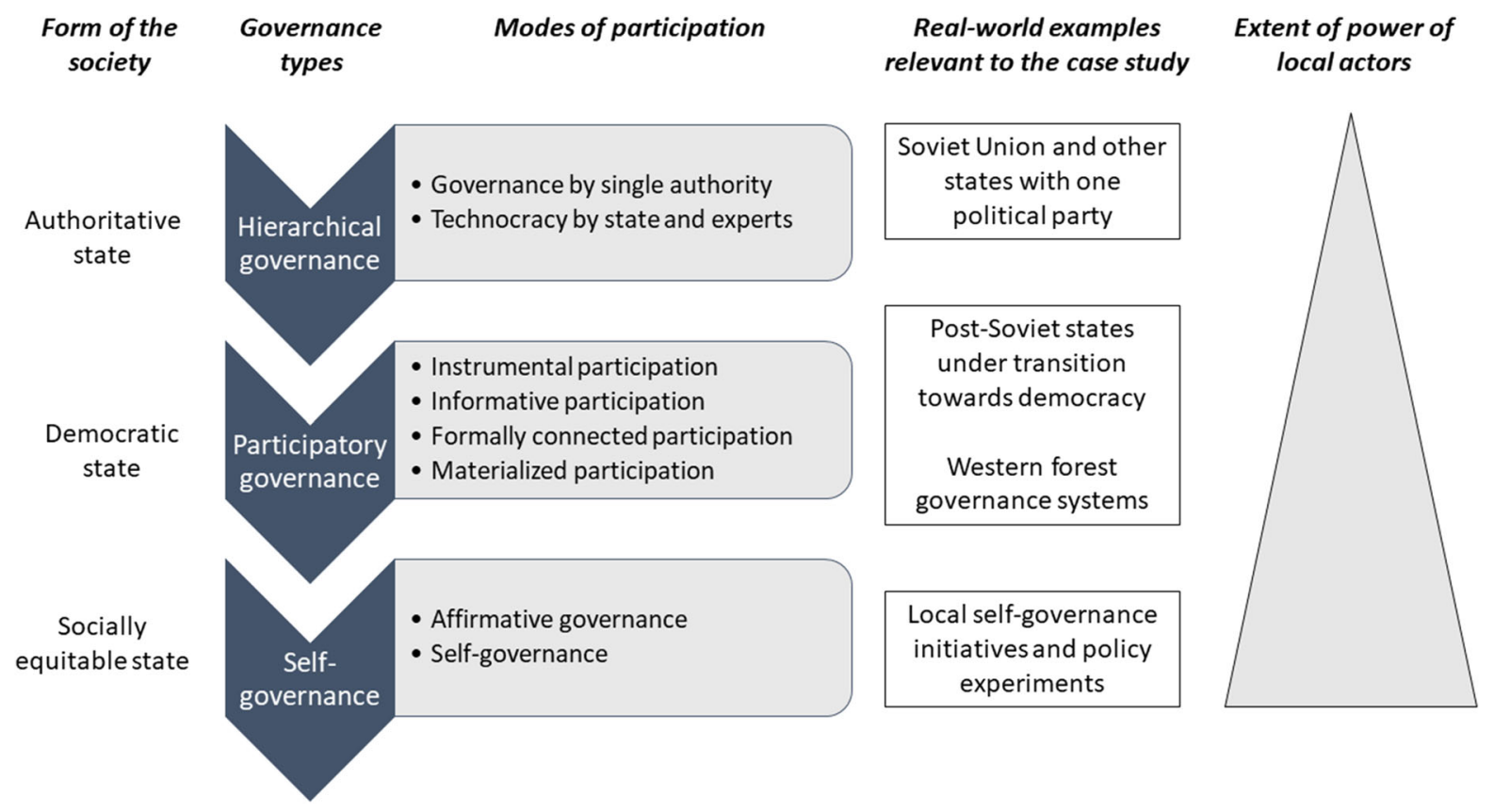

Fig. 1 Three general governance types with examples and applications

also certain sectors (e.g. forest) in current western countries may be characterized by hierarchical governance dominated by experts, for example in Canada (e.g. Howlett et al. 2009), and Finland (Raitio and Harkki 2014).

Participatory governance has been evolving also in the forest sector (Agrawal et al. 2008). Yet, as Arnstein's (1969) seminal work on ladder of participation has proposed, there are varying modes in the extent of inclusivity and power in citizen participation. In the present paper, we identify four modes of participatory governance that are examined via the Ukrainian case. In the post-Soviet Ukrainian context, the starting point is the state-controlled authoritative forest governance regime aiming for a gradual transition towards democracy (Synyakevych 2005; Soloviy et al. 2017; State Forest Agency 2017; Nijnik et al. 2018; ENPI-FLEG 2016).

When comparing the realities of the western and transition countries, we should note that in postsocialist countries, market instruments are not so common, powerful and effective. Involvement of local people in the forest decision-making process is often poor, because mechanisms for such collaboration are not developed. In addition, decision-making procedures are not transparent enough or even understandable for local people (Zahvoyska et al. 2015). In Ukraine, people are open to change, but they do not trust the bureaucrats and politicians (Nijnik and Oskam 2004). This creates a specific need for bottomup social innovations to make forest governance less authoritative and to enhance trust between experts, decision-makers and local people to facilitate transitions to well-functioning, democratic forest governance. Still, there seems to be a gap between existing policy objectives for local participation and their effective implementation due to institutional inertia in governance (Bizikova et al. 2012). Therefore, it is important that our conceptual framework (Figs. 1, 2) includes these significantly less inclusive modes of participation.

Self-governance has been discussed in many western countries with the realization that majority democracy may not be fair for local communities. There are ongoing discussions on how to achieve minority rights in democratic environmental governance systems and even how to develop decisionmaking towards self-governance (Bowie 2013; McDermott et al. 2013; Von der Porten et al. 2015; Sarkki et al. 2018). Affirmative governance acknowledges that those most affected by the decisions should also have better possibilities to influence on those 
Fig. 2 Four modes of participatory governance along the continuum from authoritative state-based forest governance to democratic forest governance

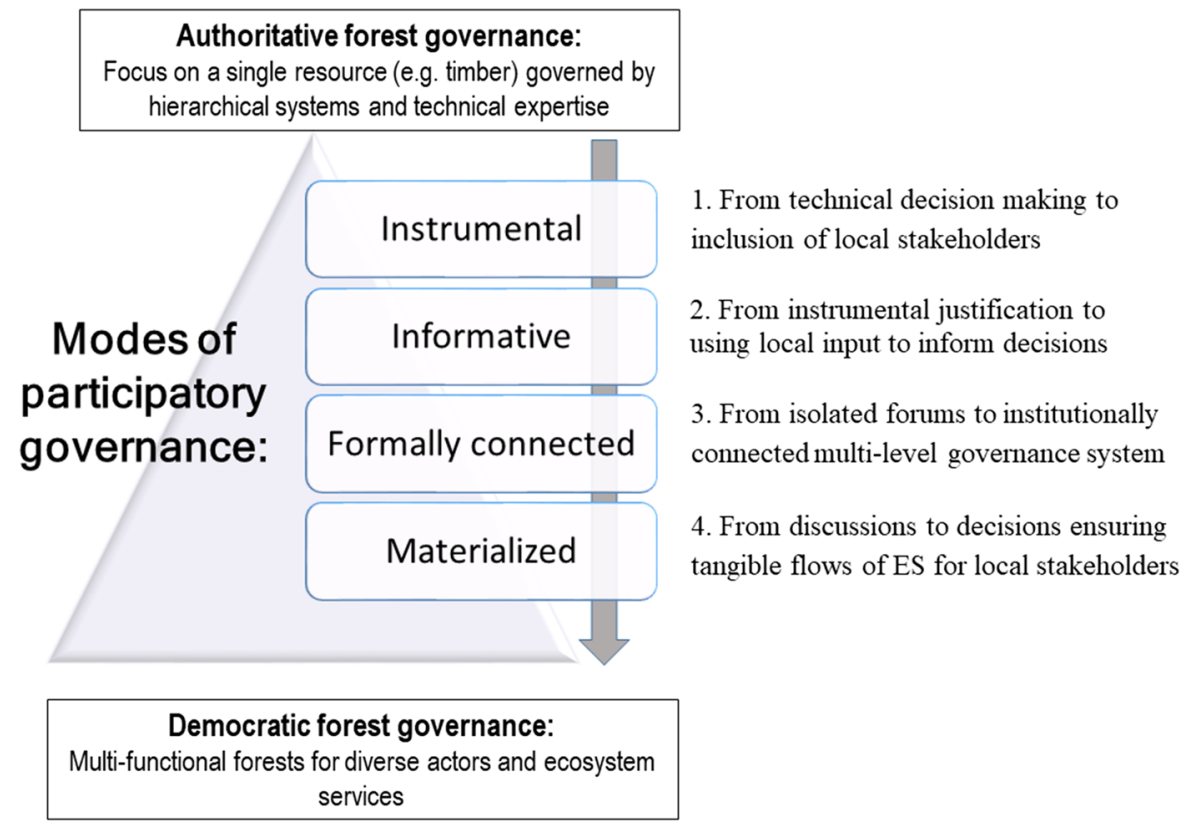

decisions than those less affected. Therefore, for example forestry decisions should be based on local participation by communities dependent on those forests (Newton et al. 2016). Self-governance of forests by local communities implies that the local people can decide on how to use the forests for their purposes (Arts and Visseren-Hamakers 2012).

With the Ukrainian case, we examine four modes of participatory governance differing in terms of the extent and quality of stakeholder participation. The instrumental participatory governance mode includes local stakeholders in decision-making processes, without necessarily giving them genuine opportunities to influence decisions relevant to them (e.g. Stirling 2008; Wesselink et al. 2011). In the informative participatory governance, local concerns are recognized and respected and decisions reflect the input of local stakeholders (see Ribot 2002). The formally connected participatory governance aims to create horizontal and vertical connections embedding local decision forums into larger governance context (Andonova and Mitchell 2010). Ideally, formally connected governance includes multiple decision nodes and forms a polycentric multi-level governance system (Ostrom 2010). The materialized participatory governance recognizes that representation of local communities in multi-level governance system is not an end in itself. That is, the anticipated benefits and responsibilities associated with the use of ES of local stakeholders need to be realized in accordance with the implications of governance decisions (Pascual et al. 2014; Kramarz and Park 2016). Only materialized decisions make participatory governance effective (Newig and Fritch 2009), and democratic (Fig. 2). The key difference between formally connected and materialized governance is that in the formally connected mode, links between local actors, state, science and market actors exist, but mere representation in governance forums does not guarantee the influential participation of local people and civil society. In the materialized mode, these actors are represented and the non-state actors have an influence on the decisions. Basically, the materialized participatory governance represents balanced and wellfunctioning democratic decision-making, which is already more or less in use in many western countries and their forest governance (see Agrawal et al. 2008).

\section{Background}

Ukrainian forest governance

Ukrainian forest policy remains state-oriented and top-down and a proper administrative and financial decentralization has not been achieved yet (Soloviy 
et al. 2017). The hierarchical forest governance has its roots in Soviet times, when forest policies were nonparticipatory, non-democratic, and centralized-with total state ownership and distribution (Soloviy et al. 2017; Melnykovych et al. 2018a, b). During the transition period, national forest legislation was adopted and new institutions established (ENPI-FLEG 2016; Table 1). However, the forest legislation in Ukraine is derived from legislation originating from the Soviet Union and problems regarding participation are foreseen in it.

During the period of independence, the status of the central forestry authority has been gradually declining (Storozhuk 2016). Currently, the Ukrainian forest governance system is plagued with insufficient legal enforcement, legislative gaps, and a poor financing and taxation system. This has led to illegal logging, corruption, a lack of transparency, uncontrolled export of round timber wood and illegal amber mining (in Polissja)—which are causing environmental problems (soil degradation and erosion, and floods in the
Ukrainian Carpathians), low productivity, loss of jobs, and depopulation of certain rural areas (Soloviy et al. 2017). It has even been estimated that the forestry sector could more than double its contribution to the national economy while simultaneously enhancing ES, conservation of landscape and biodiversity, and the opportunities for recreation and tourism (World Bank 2015).

According to the EU European Neighborhood and Partnership Instrument Forest Law Enforcement and Governance Program II (EU ENPI FLEG II), in Ukraine, state forest governance, forestry, and the forest sector as a whole, need urgent action to overcome a lack of forest policy harmonization and cross-sectoral coordination. It is becoming increasingly clear that many issues cannot be resolved within the existing organizational and legal model of forest governance, which includes elements of planned and market economy, the combination of which generates corruption risks and impedes sustainable management (http://www.enpi-fleg.org). However, changes

Table 1 Transition of legal regulations regarding forest ownership and governance in Ukraine

\begin{tabular}{ll}
\hline Year & Legal regulations \\
\hline $1991 \quad \begin{array}{l}\text { Law on the Environmental Protection } \\
\text { of Ukraine (1991) }\end{array}$ \\
Forest legislation of the Soviet Union \\
was subsequently introduced to \\
Ukraine (the Forest Code of \\
Ukrainian SSR) \\
1994 First Forest Code of Ukraine
\end{tabular}

1994 First Forest Code of Ukraine

2001 The Land Code of Ukraine \& the Forest Code

Parliamentary adoption of new Land Code caused the necessity to change the Forest Code of Ukraine (1994).

2006

The Forest Code in accordance with the acting Land Code
Forest governance and ownership

Only state ownership of forests, all forests are common national property

The Forest Code of Ukraine aims to regulate forestry management in modern socio-economic conditions and is aimed at conservation, improvement of wood quality and sustainable forest management. All forests in Ukraine belong to the state

According to the new Land Code (2001) Ukrainian forest may be state, communal (previous kolhozes governed by communal forestry enterprises) and private

This provision contradicted the Forest Code, which limited ownership of forests exclusively to the state

According to the Code, all forests of Ukraine excluding communal $(13 \%)$ and private forest $(0.5 \%)$ are state forests $(86.5 \%)$
Responsible central forestry authority

Ministry of Forestry of Ukraine

(1)


towards more participatory practices in Ukrainian forest governance are taking place (Bizikova et al. 2012) and further changes are envisaged due to the pressures exerted by various EU policies targeting sustainable forest governance (Elbakidze and Angelstam 2007; Zahvoyska et al. 2015; ENPI FLEG 2017). Following the Revolution of Dignity in 2014, the government changed its political course towards implementation of reforms aimed at European integration (ENPI FLEG 2017). However, Soloviy et al. (2017) state that the Ukrainian forest sector is still very conservative and unchanging, the reforms are happening very slowly, so changes are not as extensive as, for example, in the agricultural sector. Therefore, the reality in Ukraine's forestry does not fully correspond to society's high expectations (see Nijnik and Melnykovych 2016), creating strong need for social innovations in forest governance.

The Swiss-Ukrainian Forest Development Project in Transcarpathia (FORZA)

An example of social innovation in Ukrainian forest governance has been the FORZA project (2004-2010), which has initiated a shift towards effective participatory forest governance by identifying and assessing the role of forest governance stakeholders and piloting a two-level participatory planning process combing highly participatory village level Community Development Plans (CDP) to more technical regional Forest Management Plans. The FORZA project as a social innovation lives on after the end of the project funding, since the most active FORZA project contributors established an NGOFORZA, Agency for sustainable development of the Carpathian Region. The FORZA NGO is active in sustainable forestry projects in the Carpathian region (http://www.forza.org.ua/en).

Materials and methods

The evidence on how to build effective forest governance in Ukraine is presented in the paper by examining the FORZA case. Primary empirical sources of the FORZA project such as surveys, minutes from public hearings and stakeholder meetings and policy document analyses were screened. Annex 1 in Electronic Supplementary Material lists meetings, an overview of their participants, and topics discussed related to CDPs in Nyzhny Bystryi $(\mathrm{N}=13$ ) and Bohdan $(\mathrm{N}=8)$, and Forest Management Planning meetings $(\mathrm{N}=4)$ regarding the region where the villages are located. This screening was complemented by the already existing published reports and articles on the findings of the project (Foellmi 2006; Foellmi and Schwitter 2009; Forza 2010a, b, c).

The FORZA materials were screened first by the second and fourth author of the present paper for the purposes of identifying problems and good practices in forest management published in Sarkki et al. (2015, pp. 59-63). The first author then used inductive content analysis (Elo and Kyngäs 2008) resulting in clusters representing the four modes along the continuum from authoritative state to participatory forest governance (Fig. 2). The descriptions of the four modes of participatory governance were then written. These descriptions were finally sent to the fifth and sixth authors for elaboration and verification. The fifth and sixth authors have taken part in all the meetings described in Annex 1 in Electronic Supplementary Material, thereby having in-depth expertise on the FORZA case.

Giving that the FORZA case represents an interesting social innovation, which took place already a decade ago and was fairly local, we complemented our findings with the results from a national-level survey $(\mathrm{N}=244)$ on stakeholder awareness and perceptions of forest law enforcement and governance in Ukraine. The survey was performed in the frame of the EU ENPI FLEG II Program (henceforth ENPI FLEG II 2017). The survey methodology was designed by the EU ENPI FLEG II Program and started by identifying the key stakeholders who are impacted by or who affect the forest ecosystems. The target groups included: (a) civil servants in national ministries, sub-national (regional) and local administrations $(\mathrm{n}=106)$; (b) private sector environmental managers $(n=22)$; (c) representatives of civil society organizations $(\mathrm{n}=21)$; (d) academia representatives and researchers $(\mathrm{n}=22)$; (d) media representatives $(\mathrm{n}=23)$; (e) rural residents $(\mathrm{n}=49)$. The survey was conducted in 2014 and repeated in 2016 with the same respondents. This allowed us to identify trends in the perceptions of forest governance in Ukraine and to measure changes in awareness of the issues. To gather the questionnaires completed by the knowledgeable respondents in the forestry sector and to create a reliable and consistent database, we have used online 
professional survey software. All respondents were contacted by phone or e-mail before the link to the online survey was sent to them and they were instructed on how to complete the questionnaire and provide comments. The online survey was created along with a database to store the answers and statistical software to provide analytics. The survey aimed to find out how to improve forest governance, build capacity, and promote buy-in across a diverse set of stakeholders. To do this, the survey measured changes in awareness and perceptions of the main forest law enforcement and governance issues in Ukraine. The linkage between the FORZA case and the national survey aim to give an insight on how local scale stakeholders' requirements for forest governance supplement nationwide findings for strengthening forest governance. Also, the reason to present the national survey in this paper is chosen in order to apprise how local needs are integrated in national expectations for effective forest governance.

\section{The four modes of participatory forest governance in the Ukrainian case}

Forest governance in Transcarpathia reflects the national practices described in "Ukrainian forest governance" section. The FORZA project was initiated in 2004 in response to a catastrophic flooding event in Transcarpathia, which generated strong criticism of the authorities for existing forest management practices. The case study areas were seriously affected by flooding and clear-cut logging was blamed for the floods. This made the authorities more receptive to changing the existing governance mode. Participatory planning involving a wide range of stakeholders was initiated in two pilot areas: the villages of Nyzhny Bystryi and Bohdan (Table 2).

Participatory village-level CDPs implemented by the FORZA project provided insights into the instrumental and informative participatory modes. The CDPs took place within the rather tight timeframe organized by the project, which made a considerable effort to ensure that all relevant stakeholders were invited and their concerns addressed. The CDPs highlighted challenges in justifying local participation and in searching for local input that was relevant and could inform forestry administration in a meaningful way. The formally connected participatory governance mode was observed in the process of connecting the village level planning to regional forestry plans. The interrelation of the two types of plans aimed to coordinate community needs and interests, defined in an inter-sectoral and participatory manner, with the lower-level 10-year forest management plan. The materialized participatory governance mode was apparent when considering how this concept of two-level participatory planning was to be mainstreamed into Ukrainian forest governance. The two-level approach was first tested in two more communities - in the village of Berezne in the Khust district and the villages of Luhy and Bohdan in the Rakhiv district. The results of these pilot projects were used during the scheduled elaboration of the next 10-year forest management plan for the Transcarpathia region in 2009. The approach was then analyzed and aimed to be integrated into the forest inventory and planning instructions. Forest management plans, developed for forestry around villages, were created with the purpose of planning the next forest management period in an open, participatory manner, in accordance with 'close to nature' silviculture principles leading to materialized effects of community participation.

Instrumental participatory governance

Typical for instrumental participatory governance is that local stakeholders are present because of policy requirements or pilot projects, but that their input is not properly acknowledged. Regarding the FORZA case, forestry administration officials and foresters were accustomed to top-down technocratic planning procedures and did not have prior experience with local consultation processes before the pilot. Therefore, the two-level planning concept combining CDPs to regional forest management plans was a novel way of organizing forest governance (Foellmi and Schwitter 2009). Discussions in the CDP and forest management planning meetings stressed that forest administrators found it challenging to accept that a participatory multi-stakeholder approach could have real added value for forestry governance and believed that local people could not manage forests in a responsible or sustainable manner. Furthermore, these meetings also revealed that many forestry professionals assumed that local stakeholders would have weak professional knowledge on forestry. Many 
Table 2 Forest ecosystem services and stakeholders in Nyzhny Bystryi and Bohdan villages in the Ukrainian Carpathians (Nyzhny Bystryi 2007; Bohdan 2008)

Study area

Ownership of the area

Key local priorities for ecosystem services

Stakeholders involved in the pilot project

Pressures on ecosystem services
Nyzhny Bystryi and Bohdan villages in the Khust and Rakhiv districts of Transcarpathia, respectively, in the Ukrainian Carpathians (Total size of forest in the study areas: 4782 ha)

State-owned forests managed and logged by Khust and Rakhiv state forest enterprises and regional forest administrations impacting around 5400 people living in and around these forests

Timber harvesting benefits state forest enterprises and their local employees.

Firewood production and supply are of significant importance for local people

Cow and sheep grazing on natural pastures is a traditional livelihood important to local subsistence economies and culture. The majority of local inhabitants in the area have sheep and cows to produce milk, cheese and butter

Nature-based tourism including accommodation and board, rent of equipment, transfer services, guidance, shops

Local berry and mushroom picking, honey production, recreation and hunting, all of which are important components of local culture and subsistence economies. Hunting operates with licenses, and berry and mushroom picking is allowed for own use but requires a permit for selling. These activities are controlled by regional units of State ecological inspection of Ukraine and Regional forestry and hunting management departments.

Flood control by forests, which prevents flooding via a decrease in the volume and flow rate of surface runoff as a result of infiltration and percolation of rain water

Water availability (and quality) for prevention of droughts and preservation of water resources

Establishment of a fish farm, which requires a secure source of clean water in Nyzhny Bystryi. Logging in the watershed increased sedimentation in the river, which has been a problem for the fish farm

Village councils, inhabitants, nature-based tourism entrepreneurs, local activists, the SwissUkrainian Forest Development Project in Transcarpathia, FORZA representatives, the Transcarpathian Regional Forest and Hunting Administration, the Ukrainian state forest inventory, regional and village authorities, regional state forestry enterprises, and the water management agency

Current forest management and intensive logging focus on short-term financial outcomes and decrease the ecological values of the area. Drying/withering of spruce stands due to a complexity of reasons has resulted in extensive clear cuts in the area of Rakhiv district professional foresters also feared that community approaches to forest governance would result in a loss of their personal power and authority. On the other hand, from the perspective of local stakeholders acquired during the CDP meetings, poor information on how local stakeholders could join in and impact on the forest decision-making process was a key obstacle for participation. A mutual lack of capacities to integrate expertise of local stakeholders and forestry professionals was among the key challenges for the two-level planning approach. Stakeholders also had preconceptions of each other that were challenging to the process. For example, local community members felt that they were expected to provide technical input rather than express their concerns from their perspective. During the CDP processes it was observed that local participants also had some difficulties with understanding why they were involved and what was expected from their participation.

Current forest governance in Ukraine still has features of instrumental participation, evidenced by a lack of transparency and knowledge exchange that makes more collaborative modes of participatory governance hard. According to the interviews conducted in 2016, transparency and multi-directional information flows concerning the forest sector in Ukraine were considered insufficient. However, there was a slightly positive trend from 1.6 up to 2.0 (out of 5) between 2014 and 2016. On the positive side, the accessibility of inventory data, management plans, laws, and budgets for forests has increased from 2014 to 2016 , driven by publicly-supported legal reforms for public access to information about forestry. 
Informative participatory governance

In the informative mode of participatory governance, local stakeholders' input is used to inform decisionmaking, but governance officials are not accountable in acknowledging the local input. In the FORZA project case, the CDP processes were designed to facilitate equal involvement of all local participants in the discussions. However, the realization of this goal in CDP meetings created some frustration among the local stakeholders due to new tasks in planning posed for them. The local participants found it difficult to define community development priorities during the process, even though they knew the problems and needs of the community very well. FORZA responded to this by extensive information sharing efforts and a survey targeting all households in the Nyzhny Bystryi area. Despite this, many local stakeholders had a more wait-and-see approach to the planning, explained by the fact that the real impacts of participation on forest management actualize only after the plan (Foellmi and Schwitter 2009). Therefore, it was discovered during the CDP processes that capacity-building activities were needed for local stakeholders to learn to express their priorities in the planning meetings. A positive lesson learned from the project was that new kinds of knowledge and objectives can be produced in governance processes by "planning for people with the people" (Foellmi and Schwitter 2009). This diverges greatly from practices in which experts plan for the state. However, during the project it was noticed that co-producing knowledge with local and forestry specialist input via participatory processes took a lot of time (partly because it was the first time for everyone). The FORZA project was flexible in altering its approach. For example, the Nyzhniy Bystryi planning process took about two years with a change of working groups, modifications of methodology, and extending the process with a sociological survey. These changes were underpinned by the idea that the CDPs could result in relevant knowledge informing planning and increase mutual understanding between local stakeholders and forestry professionals.

The results of the national survey on forest governance informed us about further forest law enforcement and governance improvement initiatives led by national and international institutions, by providing points of comparison. According to the interviews done in 2016, there are problems with the capacity of stakeholders to provide influential input to forestry decision-making across Ukraine. The importance of stakeholder participation was given the lowest score by national and subnational forest-related governments. However, government support for involving civil society and forest-dependent communities in forest-related planning has a slight positive trend from 2.1 in 2014 to 2.3 in 2016 (out of 5). By analysing social media in 2017 (ENPI FLEG 2017), it is obvious that there are rising societal expectations regarding sustainable forest governance and an increasing readiness on the part of social actors (e.g. NGO and media representatives) to be the "active point" in the decision-making process, especially in highly forested regions of Ukraine. The capacity of forestry authorities to carry out consultations and to use the feedback in forest-related decision-making was assessed as medium-adequate in the survey.

\section{Formally connected participatory governance}

In formally connected governance, the degree of local input progresses from pilot projects or isolated decision forums to formally connected multi-level and participatory governance systems. The FORZA case provided an example of first building participatory local CDPs and then connecting these local priorities into the regional forest management plan. After taking into account the local input, the Lishosps (state forest management enterprises) had to submit draft plans to the local communities for review and feed-back to ensure that community priorities were truly reflected (Foellmi and Schwitter 2009). Maintaining such multi-level connections beyond the end of the pilot project requires significant changes in national forest policy and legislation. Iterative collaborations between various stakeholders are needed when advancing the integrative practices beyond the scope of a pilot project in order to introduce new processes and structures to multi-level governance systems (Foellmi and Schwitter 2009). Furthermore, participatory forestry planning can create links to other governance instruments, such as Forest Stewardship Council (FSC) certification, which mandates local participation in forestry planning, and can enable access to new markets for timber. In the current Ukraine, the FSC has strongly motivated forest professionals to interact with local people. 
The need to further develop formally-connected participatory governance in Ukraine was also recognized in the interviews conducted in 2016. It was stressed that local stakeholders' ability to influence forest policy beyond the local level depends on establishing a robust legal framework defining land tenure, forest use and ownership rights, and providing clear mechanisms for participation in forest planning. On the positive side, according to the ENPI-FLEG survey in 2016, most of the respondents considered that the State Forest Agency has the potential to improve capacity for "good" forest governance on the ground that could connect local stakeholders better with decisions made at higher governance levels. The survey has shown that awareness of the social and environmental importance of forest governance, awareness of the tools available for reform, buy-in for reforms and behaviour change among stakeholders will be hard to achieve.

\section{Materialized participatory governance}

Materialized participatory governance means that local knowledge does not merely inform decisions, but that decisions also change the distribution of benefits and burdens to better reflect local concerns. During the FORZA project, it was realized that from a national perspective, industrial timber production seems the most profitable way to use forests. However, from the local communities' perspective, alternative forest management strategies (e.g. 'close to nature' approach, uneven-aged forestry, ecosystem approach) are more beneficial (see Krynytskyy and Chernyavskyy 2014; Zahvoyska and Shvediuk 2016; Zahvoyska et al. 2017), and can function as nature-based solutions-e.g. to enhance use of non-timber forest products and to decrease flooding risks (which increase with clear-cuts). As a result of the Nyzhny Bystryi CDP, the protected area increased significantly, hiking trails have been marked, some local stakeholders have acquired eco-tourism certifications, and capacity to cope with flooding has increased. Many of these developments require a shift to 'close to nature' silviculture, which the forest management plans considered for the first time as a result of the FORZA project (Foellmi and Schwitter 2009). Local people, NGOs and scientists consider that these management strategies enable nature-based tourism, sheep and cow grazing, berry and mushroom picking, and hunting, and provide a steady flow of benefits for the communities in the long term, in contrast to industrial timber harvesting, which takes decades before being harvestable again. The changing rationale for the distribution of benefits and burdens from forest ES is likely to encounter resistance by those within and/or benefiting from the old governance system. However, there remains an important advisory role for forest administration and foresters in community-led forestry-one that can bestow prestige and respect (Krynytskyy and Chernyavskyy 2014). The role of administrators and foresters is important also because the long-term positive impact of these advances will require the full support of the regional and national forestry authorities. If this new participatory planning approach is not anchored in legislation, there is a strong likelihood that forest governance will descend again to the lower levels of the "ladder of participation". As a follow-up, we stress that after the FORZA project, the FORZA NGO and some external experts prepared a proposal for the Forest Inventory and Planning instructions, which are compulsory for all forest planning processes in Ukraine. This proposal was based on the experiences of piloting the two-level planning during FORZA project. However, after 10 years of consideration, the State Forest Agency of Ukraine did not approve this proposal.

The materialization of benefits in the form of landscape-level ES resulting from participatory forest governance is still challenging in Ukraine in general. This problem is manifested, for example, by extensive illegal logging, reflecting the fact that stakeholders need to find alternative ways to benefit from forests than those provided by forest governance (Melnykovych et al. 2018a, b). Also, the results of the survey in 2016 call for reducing social tension and conflicts in forest governance, fostering a positive business climate for a responsible private sector, and ensuring sustainable forestry management and biodiversity conservation, which was underlined as a priority for businesses, media, NGOs and local government. These represent examples of ways to materialize benefits of forest governance also for local stakeholders providing an alternative to the nationalscale benefits of industrial timber harvesting. 


\section{Discussion}

The key question for this paper is to address how the move from authoritative forest governance to democratic forest governance can take place. Figure 2 identified four steps along the "ladder of participation" that were manifested in the FORZA case and reflected via the national-level survey. Figure 3 proposes that the movement from authoritative to wellfunctioning democratic forest governance needs both: successive advancement in the ladder of participation, but also other kind of changes around the participatory processes to make them work effectively. Here, social innovations, such as the FORZA project, can work as policy experiments that can help to build socialecological resilience via sustainability transitions (see Westley et al. 2017). Therefore, the long-lasting focus of environmental governance scholars and also policy makers on public participation and ways to enhance it (e.g. Arnstein 1969; Newig et al. 2017) needs to be accompanied by changes outside and around the participatory practices. Therefore, the advancements in forest governance need to go "beyond participation".

Beyond participation

\section{From timber to multiple forest ecosystem services}

There is a trade-off between (1) provisioning services, and (2) cultural, and regulation and maintenance services, meaning that often both cannot be optimized simultaneously (Howe et al. 2014). In the case of Ukraine, the authoritative governance did not "see the wood for the trees" and focused solely on maximizing wood harvests while neglecting alternative forest ES. However, the local people in the Ukrainian case study use and value many other forest related ES (cf. Zahvoyska et al. 2017; Melnykovych et al. 2018a, b; Pelyukh et al. 2018). An exclusive focus on timber may thus obscure other ES deriving from forests that are relevant for local people (c.f. Table 2). Therefore, in order to enhance participatory forest governance, a shift in the prioritization of preferred ES is also needed. Such change provides opportunities for local participation that is meaningful for the governance agendas: local people have knowledge on traditional, parallel, and alternative practices to benefit from forest ES and can therefore provide valuable input to governance. If the focus is on technical maximization of wood production, the local participation becomes meaningless, as has been the case in Ukraine.

\section{Recognizing local expertise}

The change from authoritative state to participatory forest governance also requires changes in attitudes on who are perceived as legitimate and credible experts able to participate in forest governance decisions. Scientists can ideally act as honest brokers, who are able to facilitate knowledge integration from various sources and perspectives of diverse actors (Pielke
Fig. 3 Participation and beyond to achieve wellfunctioning democratic forest governance

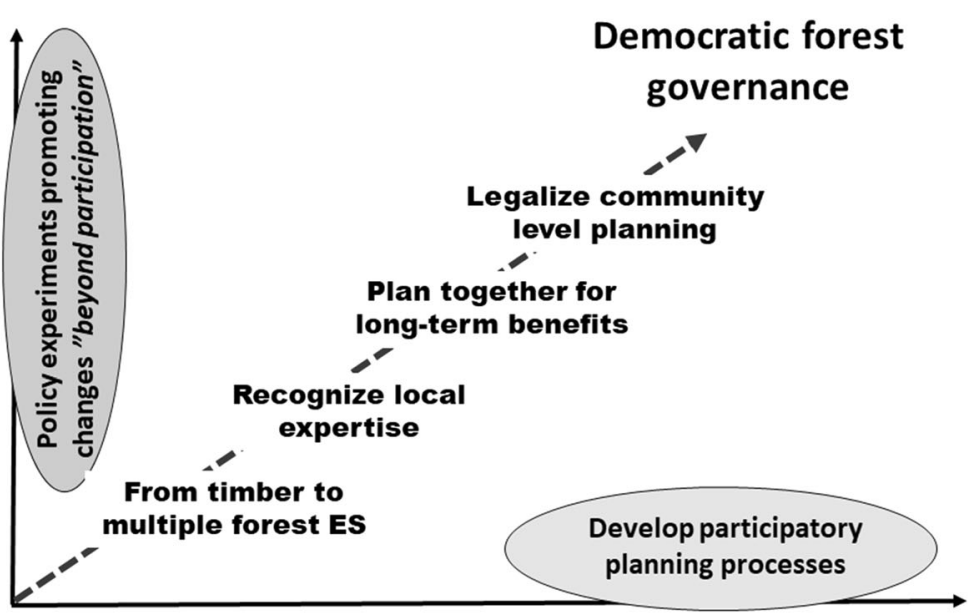

\section{Authoritative} forest governance 
2007; Rantala et al. 2017). While technical expertise on forests and forestry, and the economic interests of state-based regional forest enterprises are already taken into account in Ukrainian forest governance, there seems to be gap in valuing the expertise of local people. The Ukrainian case showed that local people, despite inhabiting, acting on and using the forests in question, may not be viewed as credible providers of knowledge, and as such the value of their input was questioned, to some extent even by themselves. How, then, could the local participation in environmental governance be legitimated in a way that would change authoritative attitudes? Steffek (2009) has proposed that legitimation may happen via goals, procedures and outcomes of governance. Goals in the case study relate to potential changes from an exclusive focus on timber to multiple ES. Procedures are about breaking down post-Soviet-style authoritative and technical decision-making. Both of these are hard to change, due to strong path dependency (Bizikova et al. 2012). The legitimation of local participation via improved outcomes of forest governance may provide a mechanism to overcome this path dependency. If the value of local participation is manifested at the level of outcomes, it could provide powerful justification for local participation. In the FORZA case, this could refer to the benefits deriving from continuous cover forestry, highlighting gains from various ES, or arise as a response to failures of current governance to avoid catastrophic events, like the flooding that functioned as a trigger for the FORZA project. Therefore, pilot projects may be able to prove the benefits of local participation and change attitudes from prioritizing authoritative and technical expertise to recognizing local expertise and thereby establishing it as an integral part of participatory forest governance.

\section{Planning together for long-term benefits}

The change from authoritative state to participatory forest governance relates also to spatial and temporal scales of ES use (see Hein et al. 2006). The Ukrainian case revealed that existing Soviet-style forestry governance was based heavily on gaining benefits at the national scale. When viewed at the national scale, felling can be optimized to ensure a steady and constant flow of benefits by planning so that every year there is an area that can be logged, while forests in other areas are growing. However, at the landscape scale, the logging can be done only once in a half century, whereas non-wood forest ES, cultural ES and regulation and maintenance ES flow constantly to the local people. Thus, authoritative state-based governance sees relations of nature and society in a certain way. Such "seeing like a state" governance practices undermine local participation (Scott 1998). Therefore, a specific spatial and temporal understanding and rationale for human-environment relations is one practice by which the state imposes its authority on local people, justifying unbalanced power relations (cf. Gofas and Hay 2010). Thus, enhancing local participation needs to be accompanied by changed state-level spatial-temporal visions of timber harvesting towards continuous flows of multiple ES at a local village level.

\section{Legalizing community level planning}

Sector-based environmental governance has been shown to be detrimental to local livelihoods in various locations (Reed et al. 2016; Sarkki et al. 2016). Among the most important challenges in Ukraine is rather the lack of opportunities for local participation under the authoritative forest governance. This problem has been conceptualized as "spatial misfit in legislation", which hinders local participation (Melnykovych et al. 2018a, b). Young and Underdal (1997) define the fit issue as follows: "The problem of fit asserts that the effectiveness and the robustness of social institutions are functions of the fit between the institutions themselves and the biophysical and social domains in which they operate" (cited from Folke et al. 2007, p. 2). The Ukrainian case highlights mismatch between institutional legislation and local ways to use the ES, thereby hindering meaningful opportunities for participation. Thus, legislation needs to change if the introduced participatory practices are to continue and be applied in other regions in Ukraine. While the sectoral challenge is often manifested for local livelihoods as problems in horizontal integration at the landscape level, the Ukrainian case is exemplary of a lack of vertical integration of landscape approaches to forest governance. The Ukrainian forest governance system includes the national level and the regional Lishosp level, but the local level is missing. Therefore, to facilitate local participation, the governance structure needs to legally include the local level to provide an institutionalized platform for the genuine 
participation of local people. The two-level planning approach combining regional forest management planning with CDPs piloted by the FORZA project provide a constructive example to enhance fit between local concerns and forest governance.

Lessons learned for social innovations

The case study showed that pilot projects can function as first steps towards social innovations. Based on this pilot project, we have learned the following lessons for social innovations.

Firstly, the social innovations or even the pilots facilitating them do not usually come from nowhere, but require a trigger or social need to actualize (Nijnik et al. 2019). In the FORZA case, local stakeholders had a social need to increasingly utilize multiple ES providing alternatives for exclusive timber production. However, in the context of a strong state-based authoritative forestry governance regime, local social needs are often suppressed by national-level decisionmaking. Therefore, a trigger was needed. In the FORZA case, it was the catastrophic flooding event precipitated by clear-cuts that functioned as a trigger to search for alternative forestry practices and governance processes. Triggers may function as justifications for new practices and could be utilized to legitimize novel governance configurations addressing social needs directed to forests and the ES they provide.

Secondly, in the area of ES there are often contradictory views and trade-offs between stakeholders and the state who have divergent preferences on the use of ES (see Hodge and Adams 2014). Local views on ES are often more holistic and diverse and often focus on regulating and cultural services rather than on provisioning services (Sarkki and Karjalainen 2015; Zahvoyska et al. 2017). The principle "planning for people with people" is useful, as local ES users should be allowed sufficient space to define what good forest governance actually is for them. Genuine opportunities for local people to participate in ES governance (Primmer et al. 2015) are therefore a crucial dimension for social innovations.

Thirdly, as discussed in "Beyond participation" section, it seems, however, that increased local participation is not enough alone, but needs to be accompanied by other simultaneous changes. Therefore, social innovations should not rely simply on the "planning with the people" principle, because other characteristics of social-ecological systems will hinder social innovation processes if they are not explicitly addressed (see Baker and Mehmood 2015). In the case of Ukraine, these other issues link especially to an institutionalized spatial rationality relying on technical state-based decision-making and preferring provisioning services over alternative forest ES.

Fourthly, a key question is how promising developments created by pilot projects and initiatives can be sustained after the project ends (EC 2014). The FORZA case pointed to the importance of changing the attitudes of forest experts and decision-makers to increasingly recognize the value of local knowledge and expertise on forests and their sustainable use in order to make lasting changes. In addition, it was stressed that without a legal framework it may be that the promising developments achieved by the FORZA project may be nullified in the future.

Finally, social innovations should be seen as processes that may start from small steps and, if successful, can be up-scaled and replicated in other contexts thereby living after the pilot projects. The FORZA case was particularly useful for identifying steps towards more democratic practices. A procedural and step-by-step perspective is relevant in cases where the social innovations aim to change governance practices characterized by strong path dependency (Beunen and Patterson 2016), as with the Soviet-style authoritarian forest governance regime in Ukraine. Transformations do not happen overnight (Avelino et al. 2017). Therefore, social innovation initiatives can benefit greatly from identifying stepwise paths towards transformation (Buckland and Murillo 2013), such as those presented in this paper.

\section{Conclusion}

The Ukrainian case and related discussions revealed a set of complexities associated with the shift from authoritative state to well-functioning democratic and participatory forest governance. In order to be effective, the successive movement from one mode of participation to the next needs to be accompanied by various other significant changes including (1) legal changes, (2) a shift away from prioritizing provisioning services towards better recognition of cultural, 
regulation and maintenance services, (3) a shift in the spatial scale at which the benefits resulting from ES are distributed, and (4) a change in the recognized types of credible expertise. The analysis and discussion done therefore have provided flesh around the assumption made in the introduction that successive movement from authoritative state to participatory forest governance needs to go "beyond participation" and address also other governance changes simultaneously. This finding is relevant in Ukraine and elsewhere (e.g. Johansson 2014; Prescott et al. 2017). The requirement for these changes in Ukraine can be partly explained by the gradual transition process from Soviet state towards forest governance resembling western democratic natural resource governance models. For example, rigid sector-based forest governance, focusing on national level economic gains from forestry as opposed to considering local benefits of forests, and reliance on technical expertise instead of local knowledge seem to be emphasized in Ukraine as a post-Soviet state.

Despite complexities, the Ukrainian case highlights that changes are taking place, such as those initiated by the FORZA project. Social innovations can justify changes by pinpointing existing problems, and illustrate novel ways to empower local communities. In particular, social innovations help in going "beyond participation" by functioning as showcases on novel practices and thereby being able to detect key barriers during the policy experiments. To initiate the transition, social innovation projects need to pay significant attention to how the novel practices can be sustained after the pilot, replicated elsewhere and up-scaled. Without such considerations, social innovation projects are likely to remain as a curiosity without lasting change. The Ukrainian case showed promise that social innovations can initiate novel ways in which forests and related ES are perceived, used, measured, valued, and governed to enhance democratic governance.

Acknowledgements Open access funding provided by University of Oulu including Oulu University Hospital. We are grateful to the Scottish Government, who supported this research through their Rural Affairs and the Environment Strategic Research Programme and the European Commission for support to the project on Social Innovation in Marginalised Rural Areas (SIMRA) provided from the European Union's Horizon 2020 research and innovation programme under Grant Agreement No. 677622. We also wish to thank the ENPI-FLEG II Program and participants in the research events. Finally, we would like to thank $\mathrm{H}$. Foellmi for providing valuable comments on the previous version of the paper and Joshua Msika for the proofreading.

Open Access This article is distributed under the terms of the Creative Commons Attribution 4.0 International License (http:// creativecommons.org/licenses/by/4.0/), which permits unrestricted use, distribution, and reproduction in any medium, provided you give appropriate credit to the original author(s) and the source, provide a link to the Creative Commons license, and indicate if changes were made.

\section{References}

Agrawal A, Chhatre A, Hardin R (2008) Changing governance of the world's forests. Science 320:1460

Andonova LB, Mitchell RB (2010) The rescaling of global environmental politics. Ann Rev Environ Res 35:255-282

Arnstein SR (1969) A ladder of citizen participation. J Am Inst Plan 35:216-224

Arts B, Visseren-Hamakers I (2012) Forest governance: a state of the art review. In: Arts B, van Bommel S, Ros-Tonen M, Verschoor G (eds) Forest-people interfaces: understanding community forestry and biocultural diversity. Wageningen Academic Publishers, Wageningen

Avelino F, Wittmayer JM, Kemp R, Haxeltine A (2017) Gamechangers and transformative social innovation. Ecol Soc 22(4):41

Baker S, Mehmood A (2015) Social innovation and the governance of sustainable places. Local Environ 20:321-334

Berkes F (2009) Evolution of co-management: role of knowledge generation, bridging organizations and social learning. J Environ Manag 90:1692-1702

Beunen R, Patterson JJ (2016) Analysing institutional change in environmental governance: exploring the concept of "institutional work'. J Environ Plan Manag. https://doi.org/10. 1080/09640568.2016.1257423

Bizikova L, Nijnik M, Kluvanková-Oravská T (2012) Sustaining multifunctional forestry through the developing of social capital and promoting participation: a case of multiethnic mountain communities. Small Scale For 11:301-319

Bohdan (2008) Bohdan community (natural resources) development plan (available only in Ukrainian), plan for development of Bogdan village, based on natural resource use. Bohdan Village Council, Bohdan

Bowie R (2013) Indigenous self-governance and the deployment of knowledge in collaborative environmental management in Canada. J Can Stud 47:91-121

Buckland H, Murillo D (2013) Antenna for social innovation pathways to systemic change: inspiring stories and a new set of variables for understanding social innovation. Greenleaf Publishing Limited, London

Cent J, Grodzińska-Jurczak M, Pietrzyk-Kaszyńska A (2014) Emerging multilevel environmental governance-a case of public participation in Poland. J Nat Conserv 22:93-102

Dennis M, Armitage R, James P (2016) Appraisal of socialecological innovation as an adaptive response by 
stakeholders to local conditions: mapping stakeholder involvement in horticulture orientated green space management. Urban For Urban Green 18:86-94. https://doi. org/10.1016/j.ufug.2016.05.010

Dryzek JS, Downes D, Hunold C, Schlosberg D, Hernes H-K (2003) Green states and social movements: environmentalism in the United States, United Kingdom, Germany, and Norway. Oxford University Press, Oxford

EC (2014) Science for environment policy in-depth report: social innovation and the environment. Report produced for the European Commission DG Environment. Science Communication Unit, University of the West of England, Bristol

Elbakidze M, Angelstam P (2007) Implementing sustainable forest management in Ukraine's Carpathian Mountains: the role of traditional village systems. For Ecol Manag 249:28-38

Elo S, Kyngäs H (2008) The qualitative content analysis process. J Adv Nurs 62:107-115

ENPI FLEG (2017) FLEG program in the forest sector of Ukraine: achievements and challenges for the future (World Bank Activities). http://www.enpi-fleg.org/site/ assets/files/2130/fleg_program_in_the_forest_sector_of_ ukraine.pdf. Accessed 5 Mar 2019

ENPI-FLEG II (2016) Governance of local forests in ENPI east countries and Russia. Gland, Switzerland: IUCN

Foellmi H (2006) Swiss-Ukrainian forest development project in Transcarpathia, Ukraine

Foellmi H, Schwitter R (2009) Forest resource planning for people with people: two-level planning for sustainable management. In: Soloviy I, Keeton WS (eds) Ecological economics and sustainable forest management developing a trans-disciplinary approach for the Carpathian Mountains. Ukrainian National Forestry University Press, Lviv, pp 270-289. http://www.uvm.edu/rsenr/wkeeton/pubpdfs/ Solivy_and_Keeton_2009.pdf. Accessed 5 Mar 2019

Folke C, Hahn T, Olsson P, Norberg J (2005) Adaptive Governance of Social-Ecological Systems. Annu Rev Environ Resour 30(1):441-473

Folke C, Pritchard L, Berkes F, Colding J, Svedin U (2007) The problem of fit between ecosystems and institutions: ten years later. Ecol Soc 12(1):30

FORZA (2010a) How communities manage forests: selected examples from around the world. Swiss-Ukrainian Forest Development Project in Transcarpathia - FORZA, L'viv, pp 51-59. http://www.forza.org.ua/sites/default/files/ communityforestry_ukrweb.pdf. Accessed 5 Mar 2019

FORZA (2010b) How communities manage forests: selected examples from around the world. Swiss-Ukrainian Forest Development Project in Transcarpathia FORZA and Swiss Foundation for Development and International Cooperation, Uzhhorod

FORZA (2010c) Swiss-Ukrainian Forest Development Project in Transkarpathia, Ukraine. Final report, pp 25-29. http:// www.forza.org.ua/sites/default/files/forza_zavershalniy_ zvit.pdf. Accessed 5 Mar 2019

Gofas A, Hay C (2010) The ideas debate in political analysis: towards a cartography and critical assessment. In: Gofas A, Hay C (eds) The role of ideas in political analysis. Routledge, London
Hein L, van Koppen K, de Groot RS, van Ierland EC (2006) Spatial scales, stakeholders and the valuation of ecosystem services. Ecol Econ 57:209-228. https://doi.org/10.1016/j. ecolecon.2005.04.005

Hodge I, Adams W (2014) Property institutions for rural land conservation: towards a postneoliberal agenda. J Rural Stud 36:453-462. https://doi.org/10.1016/j.jrurstud.2014. 05.004

Howe C, Suich H, Vira B, Mace GM (2014) Creating win-wins from trade-offs? Ecosystem services for human well-being: a meta-analysis of ecosystem service trade-offs and synergies in the real world. Glob Environ Change 28:263-275

Howlett R, Rayer J, Tollefson C (2009) From government to governance in forest planning? Lessons from the case of the British Columbia Great Bear Rainforest initiative. For Pol Econ 11:383-391

Johansson J (2014) Towards democratic and effective forest governance? The discursive legitimation of forest certification in northern Sweden. Local Environ 19(7):803-819

Kooiman J (2003) Governing as governance. Sage, Thousand Oaks

Kramarz T, Park S (2016) Accountability in global environmental governance: a meaningful tool for action? Glob Environ Pol 16:1-21

Krynytskyy HT, Chernyavskyy MV (2014) Close to nature forestry and multifunctional forest management in the Carpathian region of Ukraine and Slovakia. PE "Kolo", Uzhhorod

Lemos MC, Agrawal A (2006) Environmental governance. Ann Rev Environ Resources 31:297-325

MA (2005) Millennium ecosystem assessment: ecosystem and human well-being. Island Press, Washington, DC

McDermott M, Mahanty S, Schreckenberg K (2013) Examining equity: a multidimensional framework for assessing equity in payments for ecosystem services. Environ Sci Policy 33:416-427

Melnykovych M, Nijnik M, Soloviy I, Nijnik A, Sarkki S, Bihun Y (2018a) Social-ecological innovation in remote mountain areas: adaptive responses of forest-dependent communities to the challenges of a changing world. Sci Total Environ 613-614:894-906

Melnykovych M, Soloviy I (2014) Contribution of forestry to the well-being of mountain forest dependent communities' in the Ukrainian Carpathians. J Proc For Acad Sci Ukr Coll Sci Pap 12:233-241

Melnykovych M, Soloviy M, Nijnik M (2018) How to see the forest for the trees? Stakeholders' perceptions of sustainable forest management in Ukraine. In: Sustainable forest management for the future-the role of managerial economics and accounting. International Scientific Conference. IUFRO Unit 4.05.00-managerial economics and accounting. Book of abstracts. May 10-12, 2018, Zagreb, Croatia, pp 47-49

Newig J, Challies E, Jager NW, Kochskaemper E, Adzersen A (2017) The environmental performance of participatory and collaborative governance: a framework of causal mechanisms. Policy Stud J 46:269-297

Newig J, Fritch O (2009) Environmental governance: participatory, multi-level-and effective? Environ Pol Govern 19:197-214 
Newton P, Miller DC, Byenkya MA, Agrawal A (2016) Who are forest-dependent people? A taxonomy to aid livelihood and land use decision-making in forested regions. Land Use Pol 57:388-395

Nijnik M, Melnykovych M (2016) Exploring challenges to sustainability in the provision of ecosystems services by upland forests in Scotland and Ukraine. In: Sekot W, Toscani P, Ungerböck E (eds) International Union of Forestry Research Organizations (IUFRO) symposium proceedings: advances and challenges in managerial economics and accounting, pp 85-86

Nijnik M, Nijnik A, Sarkki S, Munoz-Rojas J, Miller DR, Kopiy S (2018) Is forest related decision-making in European treeline areas socially innovative? A Q methodology enquiry into the perspectives of international experts. For Policy Econ 92:210-219

Nijnik M, Oskam A (2004) Governance in Ukrainian forestry: trends, impacts and remedies. Int J Agric Res Govern Ecol 3:116-133

Nijnik M, Secco L, Miller D, Melnykovych M (2019) Can social innovation make a difference to forest-dependent communities? For Pol Econ 100:207-213

Nijnik M, van Kooten G (2006) Forestry in the Ukraine: the road ahead? Reply for. Policy Econ 8:6-9

Nyzhny Bystryi (2007) Nyzhniy Bystryy watershed development plan. Economics Department of Khust Rayon State Administration, Khust

Ostrom E (2010) Polycentric systems for coping with collective action and global environmental change. Glob Environ Change 20:550-557

Paavola J, Hubacek K (2013) Ecosystem services, governance, and stakeholder participation: an introduction. Ecol Soc 18(4):42

Pascual U, Phelps J, Garmendia E, Brown K, Corbera E, Martin A, Gomez-Baggethun E, Muradian R (2014) Social equity matters in payments for ecosystem services. Bioscience 64:1027-1036

Pelyukh O, Zahvoyska L, Maksymiv L (2018) Analysis of stakeholders' interaction in the context of secondary Norway spruce stands conversion in the Ukrainian Carpathians Sustainable Forest management for the future - the role of managerial economics and accounting. IUFRO Research unit(s): 4.05.00, 4.05.01, 4.05.02, 4.05.03. Book of abstracts. May 10-12, 2018, Zagreb, Croatia, pp 22-24

Pielke R (2007) The honest broker. Making sense of science in policy and politics. Cambridge University Press, Cambridge

Pohl C (2008) From science to policy through transdisciplinary research. Environ Sci Policy 11:46-53

Prescott GW, Sutherland WJ, Aguirre D, Baird M, Bowman V, Brunner J, Connette GM, Cosier M, Dapice M, De Alban JDT, Diment A et al (2017) Political transition and emergent forest-conservation issues in Myanmar. Conserv Biol 31:1257-1270

Primmer E, Jokinen P, Blicharska M, Barton DN, Bugter R, Potschin M (2015) Governance of ecosystem services: a framework for empirical analysis. ECOS Serv 16:158-166

Raitio K (2012) New institutional approach to collaborative forest planning on public land: methods for analysis and lessons for policy. Land Use Policy 29:309-316. https:// doi.org/10.1016/j.landusepol.2011.07.001
Raitio K, Harkki S (2014) The disappearing chain of responsibility: legitimacy challenges in the political governance of Finnish Forest and Park Service. Land Use Policy 39:281-291

Rantala L, Sarkki S, Karjalainen TP, Rossi P (2017) How to earn the status of honest broker? Scientists' roles facilitating the political water supply decision making process. Soc Nat Res 30:1288-1298

Reed J, Van Vianen J, Deakin EL, Barlow J, Sunderland T (2016) Integrated landscape approaches to managing social and environmental issues in the tropics: learning from the past to guide the future. Glob Change Biol 22:2540-2554

Ribot JC (2002) Democratic decentralization of natural resources. Institutionalizing public participation. World Resources Institute, Washington, DC

Sarkki S (2017) Governance services: co-producing human well-being with ecosystem services. ECOS Serv 27:82-91

Sarkki S, Grunewald K, Nijnik M, Zahvoyska L, Abraham EM, Alados CL, Bellamy C, Bratanova-Dontcheva S, Jokinen M, Kollar J, Krajčí J (2015) SENSFOR deliverable 4. Problems and proposals for good environmental management: empirical assessment of European treeline areas. http://www.sensfor-cost.eu/images/Deliverable\%204.pdf. Accessed 5 Mar 2019

Sarkki S, Heikkinen HI, Herva V-P, Saarinen J (2018) Myths on local use of natural resources and social equity of land use governance: reindeer herding in Finland. Land Use Policy 77:322-331

Sarkki S, Heikkinen HI, Karjalainen TP (2013) Sensitivity in transdisciplinary projects: case of reindeer management in northern Finland. Land Use Policy 34:183-192

Sarkki S, Karjalainen TP (2015) Ecosystem service valuation in a governance debate: practitioners' strategic argumentation on forestry in Northern Finland. ECOS Serv 16:13-22

Sarkki S, Komu T, Heikkinen HI, Acosta García N, Lépy É, Herva V-P (2016) Applying a synthetic approach to the resilience of Finnish reindeer herding as a changing livelihood. Ecol Soc 21(4):14. https://doi.org/10.5751/ES08819-210414

Scott J (1998) Seeing like a state: how certain schemes to improve the human condition have failed. Yale University Press, New Haven

Soloviy IP, Nijnik M, Deyneka AM, Melnykovych M (2017) Reimagining forest policy, institutions and instruments through concepts of ecosystem services and social innovations: Ukraine in the focus. Sci Bull 27(8):82-87

Sotirov M, Storch S, Aggestam F, Giurca A, Selter, BaychevaMerger A, Eriksson T, Sallnäs L, Trubins O, Schüll R, Borges E, Mcdermott J, Hoogstra-Klein C, Hengeveld M, Pettenella D (2016) Forest policy integration in Europe: lessons learnt, challenges ahead, and strategies to support sustainable forest management and multifunctional forestry in the future. https://doi.org/10.13140/rg.2.1.2099. 9288

State Forest Resource Agency (2017) Strategy for sustainable development and institutional reform of the forestry and wildlife management in Ukraine for the period up to 2022. http://dklg.kmu.gov.ua/forest/control/uk/publish/article? art_id=182224\&cat_id=166243. Accessed 5 Mar 2019

Steffek J (2009) Discursive legitimation in environmental governance. For Pol Econ 11:313-318 
Stirling A (2008) "Opening up" and "closing down": power, participation and pluralism in the social appraisal of technology. Sci Technol Hum Values 33:262-294

GRAID. Stockholm Resilience Centre (2017) Chapter 3. Creating a good anthropocene: social-ecological innovations. http://whatisresilience.org/en/chapter-3/. Accessed 5 Mar 2019

Stokols D (2006) Toward a science of transdisciplinary action research. Am J Commun Psychol 38:63-77

Storozhuk V (2016) Overall assessment of forest governance in Ukraine. ENPI-FLEG II report. ENPI-FLEG, Kyiv, p 84

Synyakevych I (2005) Forest policy. ZUKC, Lviv (in Ukrainian)

Verburg R, Selnes T, Verweij P (2016) Governing ecosystem services: national and local lessons from policy appraisal and implementation. ECOS Serv 18:186-197

Von der Porten S, De Loë R, Plummer R (2015) Collaborative environmental governance and indigenous peoples: recommendations for practice. Environ Pract 17:134-144

Wesselink A, Paavola J, Fritsch O, Renn O (2011) Rationales for public participation in environmental policy and governance: practitioners' perspectives. Environ Plan 43:2688-2704

Westley F, McGowan K, Tjörnbo O (eds) (2017) The evolution of social innovation. Building resilience through transitions. Edward Elgar Publishing, Cheltenham
World Bank (2015) World development indicators. World DataBank. World Bank, Washington, DC

Young O, Underdal A (1997) Institutional dimensions of global change. International Human Dimensions Programme on Global Environmental Change IHDP Scoping Report, Bonn

Zahvoyska L, Nijnik M, Sarkki S, Nijnik A, Pelyuch O (2015) Insights into treeline ecosystem services of the Ukrainian Carpathians from a stakeholders' perspective: an analysis of challenges for adaptive governance. J Proc For Acad Sci Ukr Coll Sci Pap 13:193-200

Zahvoyska L, Pelyukh O, Maksymiv L (2017) Methodological considerations and their application for evaluation of benefits from the conversion of even-age secondary Norway spruce stands into mixed uneven-aged woodlands with a focus on the Ukrainian Carpathians. Aust J For Sci 134:251-281

Zahvoyska L, Shvediuk I (2016) Cost-benefit analysis of reforestation process: Maley Polissya case study. J Proc For Acad Sci Ukr Coll Sci Pap 14:236-243 (In Ukrainian)

Publisher's Note Springer Nature remains neutral with regard to jurisdictional claims in published maps and institutional affiliations. 